\title{
Jan Fryček in the Inventories of the Premonstratensian Monastery in Nová Řiše
}

\author{
Lukáš Pavlica / lukpavlica@gmail.com \\ Department of Musicology, Faculty of Arts, Masaryk University, Brno, CZ
}

\begin{abstract}
The study focuses on the inventories of the musical collection of Premonstratensian Monastery in Nová Řiše (Neureisch). The aim is to present the inventories stored in Moravské zemské muzeum (Moravian Land Museum) and Moravský zemský archiv (Moravian Land Archive) and mainly those inventories found directly in Nová Říše. The inventory could serve not only as an overview of the specific items stored in the collection at the specific time, but due to its nature, many inventories, in the course of time, served as the sorting materials and therefore allow us to understand the system and structure of a given collection even further. From the presented inventories the study chooses two of those stored in Nová Řiše because unlike the rest of the inventories, these provide the most information of the evolution of the collection. The pencil-written notes give a significant amount of details about the missing compositions or wrong authorship of specific musical pieces. Although the studied inventories provide a lot of interesting data, it is only a tip of an iceberg and thus further research should be applied to all the other inventories of the musical collection.
\end{abstract}

\section{Key words}

Nová Říše, musical collection, inventory, Jan Fryček, Mainhard Schuberth, Josef Kallina, Jan Mach, Telč 
Premonstratensian monastery in Nová Ř́šse is located in the Bohemian-Moravian Highlands in Jihlava (Iglau) district nearby Telč (Teltsch), another culturally important town in the region. ${ }^{1}$ Although the musical collection of the monastery with its 640 inventory numbers belongs amongst relatively smaller collections, its structure, content and overall evolution help to uncover the information not only about the musical life of the monastery, but also about the musical education in Moravia. ${ }^{2}$

The musical collection began to emerge at the turn of the $18^{\text {th }}$ and $19^{\text {th }}$ centuries and its largest expansion occurred in the first half of the $19^{\text {th }}$ century. ${ }^{3}$ In 1929 , the collection was catalogued by the musicologist Robert Smetana. ${ }^{4}$ The collection is divided into two approximately equally sized sections A and B. ${ }^{5}$ The section A consists mainly of secular music and section B primarily of sacred music. ${ }^{6}$ Regenschori, the double bassist and occasional composer Mainhard Schuberth (1800-1888) has a great deal of credit for expanding the music collection. From 1829 to 1848 he held the positions of cantor,

1 Insight into the history of the monastery from the point of view of one of its members: ŽÍDECKÝ, Cyril. Beschreibung und kurze Geschichte des Prämonstratenser-Chorherrenstiftes Neu-Reisch in Mähren. Würzburg \& Wien: Verlag von Leo Woerl, 1882.

More recent summary of the history of the monastery: PAŘEZ, Jan - KROUPA, Jiří. NOVÁ ŘÍŠE (Jihlava) Bývalý konvent premonstrátek Matky Boží (P. Marie) s kostelem sv. Petra a Pavla, následně kanonie premonstrátů. In FOLTÝN, Dušan a kol. Encyklopedie moravských a slezských klášterů. Praha: Libri, 2005, pp. 456-460.

About the history of the monastery as well as about the local literary brotherhood writes extensively Vladimír Maňas: MAŇAS, Vladimír. Hudební tradice. In NEKUDA, Vladimír. Dačicko, Slavonicko, Telčsko. Brno: Muzejní a vlastivědná společnost v Brně, 2005. pp. 402-407.

Maňas also offers a great insight into the history of the musical activities in Telč and describes the activities of both the Jesuit Order and the aristocracy.

2 Around the year 1800, the abbot of the monastery Jan Nepomuk Pelikán established in Nová Říše a boarding school, a great amount of secular musical compositions surviving in the collection of the monastery could probably be attributed to this. Together with the boarding school a student's orchestra originated as well.

3 SVOBODOVÁ-PALEČKOVÁ, Věra. Hudební sbírka kláštera premonstrátů v Nové Říši. Časopis Moravského muzea v Brnĕ. XXXVI-1951, p. 3.

However, a reader should treat the study by Svobodová-Palečková carefully, as there are several problems with it: e.g. on p. 5 Mainhard Schuberth is said to be a regenschori from 1800 to 1830 , but Schuberth was born on $17^{\text {th }}$ February 1800 .

4 Robert Smetana (1904-1988) was an Austrian born Czech musicologist, collector of Moravian folk songs and university pedagogue. From 1924 to 1932 Smetana worked in the Musical archive (today Department of the History of Music) of Moravské zemské muzeum, for which he made the card catalogue (ranging from A17.654 to A18.294) of the musical collection of the monastery. For the convenience, the study uses primarily signatures from this catalogue.

5 A1-A354, B1-318. The attentive reader will probably not miss the fact that there are more of the signatures A and B (672) than there are signatures in Smetana's catalogue (640). The reason for this is that sometimes there are bundles of multiple compositions under one signature. For example, under sign. A17.947 we can find Liebesmelancholie and Les Glockes du Monastere (both by anonymous composer), labelled as A312 and A313, respectively.

6 Trios, quartets, and partitas from various composers both famous and local occupy an important position in the Section A of the musical collection. An equally significant and interesting segment of the music collection are the piano and guitar arrangements of various operas. E.g. Ouverture from Don Juan by W. A. Mozart for fortepiano (CZ-Bm: A17.812) and so on. The collection also contains several complete operas, e.g. W. A. Mozart (Don Giovanni - A17.968, Die Zauberflöte - A17.972, Le nozze di Figaro - A17.970), Salieri (La Grotta di Trofonio - A17.971, Armida - A17 859) or for example P. A. Guglielmi (La pastorella nobile - A17.969). 
regenschori and librarian. ${ }^{7} \mathrm{He}$ also worked as a professor of mathematics and physics in Brno. ${ }^{8}$ Although he composed himself, his works appear only marginally in the collection. Apart from his Graduale and Motteto in $G$, the collection also preserves his harmony textbook, which could shed more light on the music education in the monastery. From the first half of the $19^{\text {th }}$ century, the names of several cantors and composers who also participated in the expansion of the collection are known: until 1829, the composer Josef Kallina (1760-1829) ${ }^{9}$ taught in Nová Říše, Jan Mach ${ }^{10}$ was another local teacher and organist who expanded the collection. Probably the most interesting of all the teachers active in Nová ̌̌íše was the cantor, composer, and organist Jan Fryček (1758-1826). ${ }^{11}$ This interesting figure of the musical life in Nová Říše was the most prolific composer of all the cantors at the time in Nová Ŕiše. ${ }^{12}$ There are at least 28 surviving compositions (both liturgical and secular) of his and some of the missing ones might probably still be in the depths of the musical collection in Nová Ř́še.

\section{Inventories}

The inventories of music and musical instruments are important sources for researching the musical collection, its development, and the musical life of the monastery in general. ${ }^{13}$ There are several preserved inventories related to the musical collection of the

7 ČERNUŠÁK, Gracián. Schuberth Mainhard. In ČERNUŠÁK, Gracián - ŠTĚDROŇ, Bohumír NOVÁČEK, Zdenko (eds.). Československý hudebni slovnik osob a institucí. Sv. 2., Praha: Státní hudební vydavatelství, 1965, p. 496.

8 Ibid.

9 Cantor and composer born in 1760 in Hluboká (Třebíč district). He served as a teacher in Nová Říše, where he came from Náměšt nad Oslavou and where he served in the ensemble of Haugwitz family. (MAŇAS, Vladimír. Hudební tradice, pp. 392-431.) After his death in 1829, the monastery bought his musical collection. (More on that further on.)

10 Mach served as an organist from 1830 to 1873. His Pange lingua in D No. 9 (A17.993, composed 30th December 1830) and Pange lingua in D No. 10 (A18.000, composed 1833) suggest there were more of his compositions in the musical collection.

11 He worked in Nová Říše from 1798 to1826. On 22nd January 1788 Fryček and his wife Maria Anna had a son Kristian, who published a book Písně a prưpovédi na celé učení křestansko-katolického náboženství dle pořádku katechismu in Prague in 1834.

12 Apart from his compositional activities, teaching- and his duties as an organist, he also contributed several songs to gubernatorial collection. (VETTERL, Karel. Volkslied-Sammelergebnisse in Mähren und Schlesien aus dem Jahre 1819. In VYSLOUŽIL, Jiří (ed.). Sbornik prací Filozofické fakulty brněnské univerzity. Brno: Universita J. E. Purkyně, 1973, roč. 22, č. H8, p. 103, 106, 107, 115.) More on that matter at: VETTERL, Karel - HRABALOVÁ, Olga. Guberniálni sbirka pisni a instrumentální hudby z Moravy a Slezska z roku 1819. Strážnice: Ústav lidové kultury, 1994.

13 Jiří Fukač provides an important methodological and historical insight into the research of inventories. Fukač compares different approaches to inventories (and to listed items) at the medieval times, renaissance and in the more recent years: FUKAČ, Jiř́. Zur inneren Systematik musikalischer Verzeichnisgattungen. In VYSLOUŽIL, Jiří (ed.). Sbornik prací Filozofické fakulty brněnské univerzity. Brno: Universita J. E. Purkyně, 1967, roč. 16, č. H2, pp. 21-30. Thought on further development of the historical research of the inventories also provides a paper by Vladimír Maňas: MAŇAS, Vladimír. K problematice hudebních inventářu: několik 
Premonstratensian monastery in Nová ̌̌́íse. Firstly, there are inventories stored in Moravský zemský archiv (Moravian Land Archive). There is an inventory of sheet music received by Josef Kallina on $31^{\text {st }}$ October $1826 .{ }^{14}$ A part of it comes from the collection of resigned Fryček. ${ }^{15}$ The same date of $31^{\text {st }}$ October 1826 may be found on the inventory of musical instruments and music belonging on the choir loft, made and signed by Josef Kallina once again. ${ }^{16}$ Jan Mach based his inventory of musical instruments ${ }^{17}$ and his inventory of musical compositions ${ }^{18}$ on these two inventories. In his inventories, Machhe combined the musical pieces from both Kallina's inventories. The last inventory dates to $12^{\text {th }}$ March 1832 and was made by Pater Mainhard Schuberth. ${ }^{19}$ The inventory mentions the musical pieces formerly belonging to Josef Kallina that were bought and added to the collection of the monastery after his death in 1829. The copies of all these inventories (except for CZ-Bsa: E 58, k. 252, f. 12-13) can be found in the Department of the History of Music of Moravské zemské muzeum (Moravian Land Museum). ${ }^{20}$

In the archive of the Monastery and even in the same cabinet where the musical compositions are located, is a folder Inventár̆ kưrnich hudebnin při pralátském (sic!) chrámu Páně v Nové Řísi (Inventory of the choir loft's sheet music at the prelate's temple of the Lord in Nová Říše). ${ }^{21}$ In this folder, there are three inventories, their transcriptions ${ }^{22}$ and two documents concerning the moving of the collection from the Moravské zemské muzeum, where it was stored since 1950, back to Nová Říše between 1993 and 1995. The most recent is the inventory no. 3 made in 1914. It comes from the hands of regenschori Filip Pořiska (1843-1916), who came to Nová Ř́íse in $1893 .{ }^{23}$ Due to its size and the date of its origin, it is far beyond the scope of this study and it will be a subject of a separate study and further research.

This article focuses primarily on the two other inventories preserved in the folder inventory no. 1 and inventory no. 2. ${ }^{24}$ Both inventories were signed by Jan Mach and Mainhard Schuberth on $30^{\text {th }}$ July 1829 and in the course of time used quite extensively, as they are filled with pencil-written notes which proven to be more than helpful to identify specific compositions of Jan Fryček, the key figure of the current research.

doplňujících poznámek k heslu Katalog Jiřího Fukače ve Slovníku české hudební kultury. Musicologica Brunensia. 2016, roč. 51, č. 2, pp. 81-94.

14 Moravský zemský archiv (further as CZ-Bsa): E 58, k. 252, f. 11, 20.

15 This information is featured in every other inventory based on this one made by Kallina.

16 CZ-Bsa: E 58, k. 252, f. 15.

17 CZ-Bsa: E 58, k. 252, f. 14.

18 CZ-Bsa: E 58, k. 252, f. 12-13.

19 CZ-Bsa: E 58, k. 252, f. 16-19.

20 CZ-Bm: 85.233/G 2.158, 85.234/G 2.159, 85.235/G 2.160.

21 CZ-Bm: G 26.

22 These transcriptions label the inventories as inventory no. 1, no. 2 and inventory no. 3, therefore the study mentions these documents in the same manner.

23 ŠTĚDROŇ, Bohumír. Pořiska Filip. In ČERNUŠÁK, Gracián - ŠTĚDROŇ, Bohumír - NOVÁČEK, Zdenko (eds.). Československý hudebni slovnik osob a institucí. Sv. 2., Praha: Státní hudební vydavatelství, 1965, p. 345.

24 Both with attached transcriptions made by Robert Smetana. 


\section{Inventory No. 1}

The first of the two inventories is very similar in its structure to the inventory of musical compositions written by Josef Kallina on the $31^{\text {st }}$ October $1826 .{ }^{25}$ Both start with a note mentioning the part of the collection being from the property of Jan Fryček and both maintain basically the same layout. The major difference is the number of columns on the page.

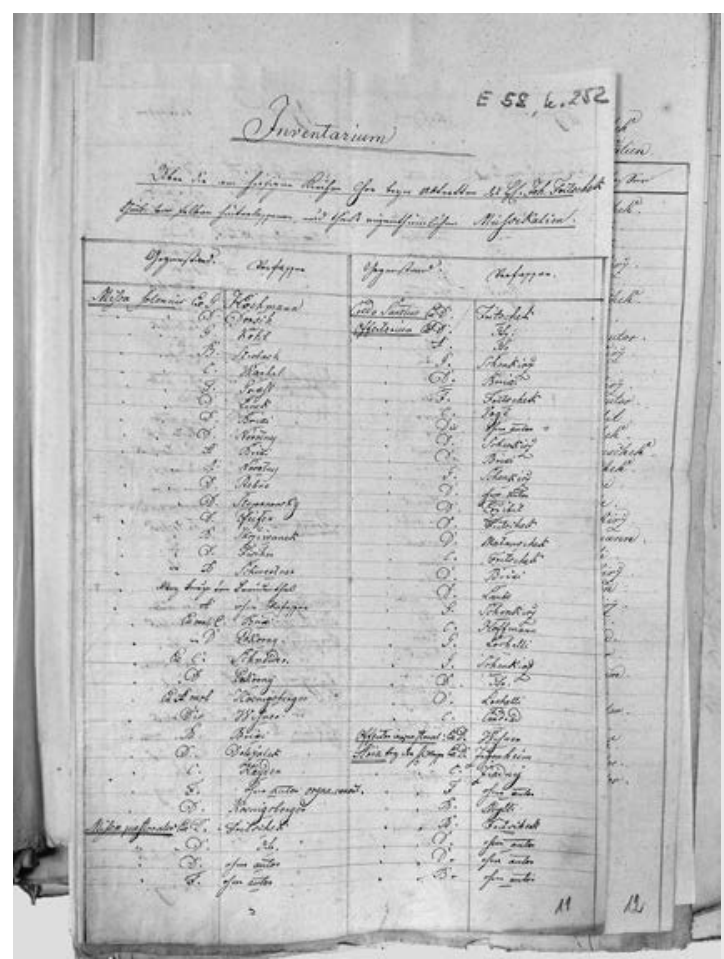

Fig. 1 Kallina's inventory (title page)

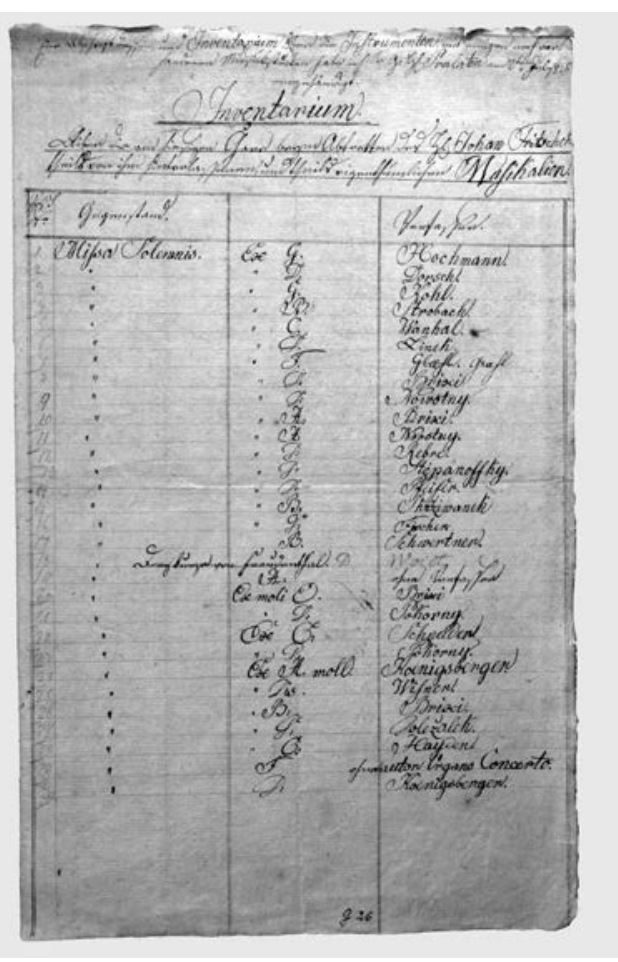

Fig. 2 Inventory no. 1 (title page)

The inventory no. 1 has a great number of pencil-written notes which not only help to identify music, but they also shed light on the evolution of the musical collection. The same numbers that are written in the inventory no. 1 were also written on every title page of a corresponding manuscript and probably served during the cataloguing of the collection or as a proof of availability.

A typical title page of a musical manuscript in Premonstratensian monastery in Nová Ŕíše bears several different signatures. The most useful for the sorting are the

25 Above mentioned CZ-Bsa: E 58, k. 252, f. 11. 
above-mentioned pencil written numbers occurring in the inventories and on the title pages, these numbers allow for a quick and reliable recognition of almost any composition in the list. Another important signature for the understanding of the evolution of the collection is the signature sorting the manuscripts into two different groups - cabinet $\mathrm{A}$ and cabinet $\mathrm{B}$. This signature consists of a letter indicating the cabinet and a number indicating a specific sheet music (e.g. B 295, A21, etc.). Over time, there were also added notes numbering the musical pieces, but without the information on the cabinet (e. g. "Č́s. 295", etc.). Another very important signature comes from the catalogue of Moravské zemské muzeum sorting the compositions from A17.654 to A18.294. If the composition falls under a specific category (e.g. Missa Pastoralis), the title page also contains a number of the musical pieces in the category (e.g. No. 8. Missa Pastoralis). When exactly these notes came to be is unknown and it is impossible to say with certainty who made them right at this moment, but there is a possibility that these notes and figures

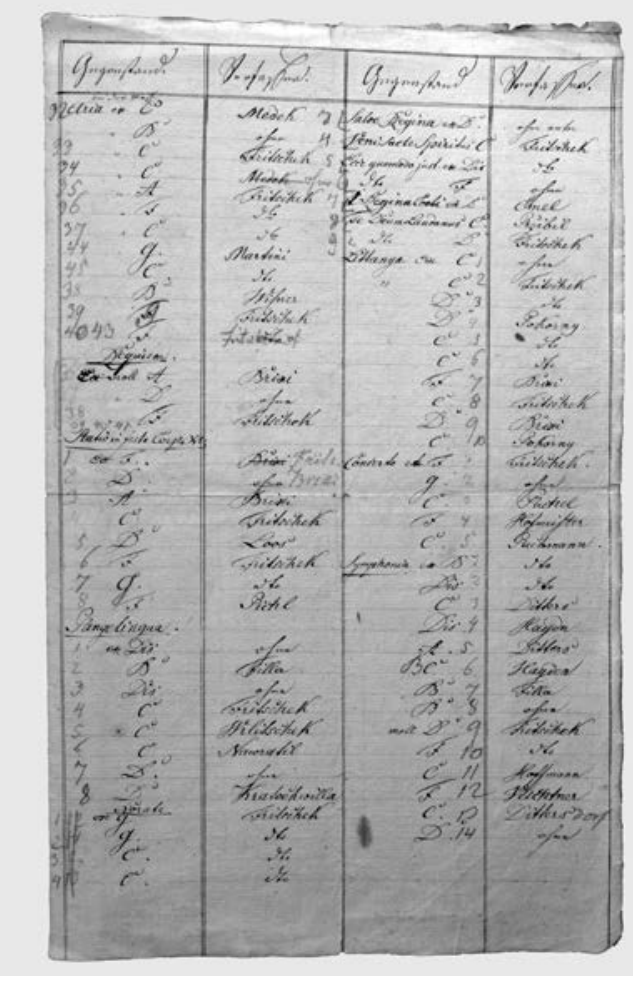

Fig.3 Page of Inventory no. 1, Rorate in the lower left corner

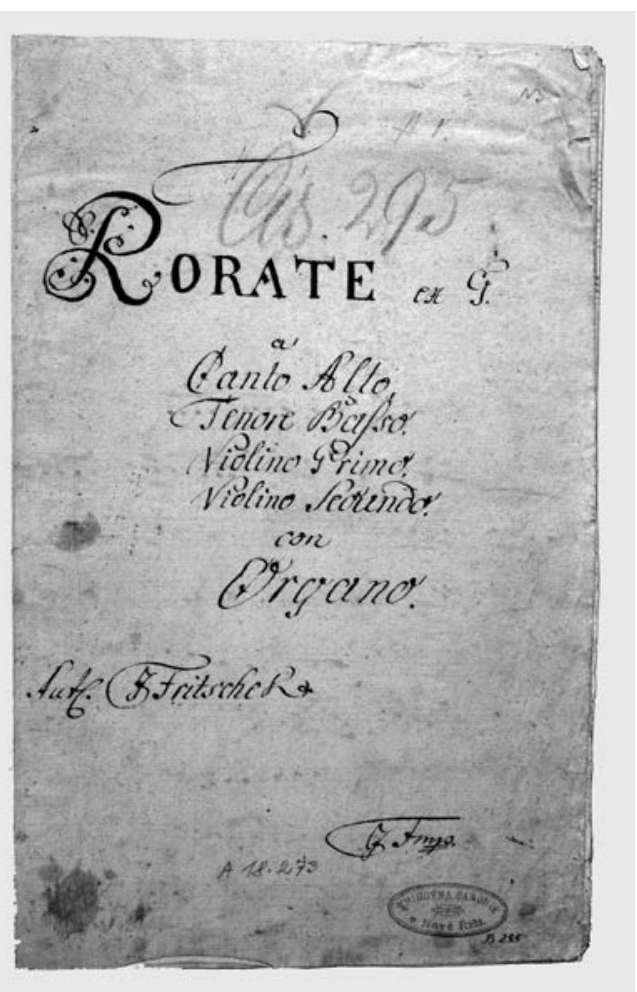

Fig. 4 Title page of Rorate ex G (A18.273) with the mentioned numbering

were edited at least once. ${ }^{26}$ Interestingly enough, the numbers in the inventory are writ-

26 For example, two Trios of Fryček and one of Stamic (it is unclear which Stamic) have their respective numbers $(19,20,13)$ next to the key $(\mathrm{B}, \mathrm{F}, \mathrm{B})$, which means that at the time when these figure were written, the 
ten by a pencil, although the column "Pos[ition]. N[umer]o." is pre-labelled by ink just like every other category. It means that for some reason the numbers of the position in the inventory were not written when the inventory was originated. ${ }^{27}$

The aim of the transcription was to preserve the look and the form of the original as much as possible. The words and numbers in bold are the ones written by a pencil, the regular font is meant for ink. With a careful comparison of the numbers written in inventory no. 1 and on the title pages of Fryček's manuscript, it was possible to identify specific musical pieces and to provide them with a signature from Moravské zemské muzeum (CZ-Bm). ${ }^{28}$ The CZ-Bm signature was chosen because it pairs with the catalogue made by Robert Smetana, which provides the most basic and important information about the pieces to anyone interested. These signatures were added to the transcription for a quicker identification and are written in italic type of font and as such are not to be found in the original source.

\section{Transcription of the inventory no. 1}

Eine Abschrift dessen, und Inventarium über die Instrumenten, mit einigen nach vorhandenen Musikstücken habe ich Fr. G: Hl Praelaten am 2ten July 826 eingehändigt.

\section{Inventarium.}

Über die am hiesigen Chor beym Abtretten des H. Johan Fritschek Theils von ihm hinterlassenen, und theils eigen thümlichen Musikalien.

\begin{tabular}{|c|c|c|c|}
\hline Pos. No. & Gegenstand. & & Verfasser: \\
\hline 1 & Missa Solemnis. & Ex G. & Hochmann. \\
\hline 2 & 11 & „D. & Dorsch. \\
\hline 3 & 11 & ${ }_{11} \mathrm{G}$ & Kohl. \\
\hline 4 & II & ,B & Strobach. \\
\hline 5 & " & ${ }_{11} \mathrm{C}$ & Wanhal. \\
\hline 6 & $\prime \prime$ & $\because \mathrm{D}$ & Linek. \\
\hline 7 & "1 & ${ }_{11} \mathrm{~F}$ & Glaht. Grahl \\
\hline 8 & $\prime \prime$ & " $\mathrm{D}$ & Brixi \\
\hline 9 & 11 & "D: & Nowotny. \\
\hline 10 & 11 & "A: & Brixi. \\
\hline 11 & 11 & "A: & Novotny. \\
\hline
\end{tabular}

compositions were probably still available, but next to the composers' names are another pencil written notes ("chybí", missing) suggesting the manuscripts are no longer available.

27 Neither Kallina's inventory (CZ-Bsa: E 58, k. 252, f. 11), nor the combined inventory of Mach (CZ-Bsa: E 58, k. 252, f. 12-13) contain the "Pos. No." column.

28 The inventory itself provides much more possibilities to identify compositions of other composers, but this task is far beyond the scope of this study. 


\begin{tabular}{|l|l|l|l|}
\hline Pos. No. & Gegenstand. & & Verfasser: \\
\hline $\mathbf{1 2}$ & " & " D: & Rebre. \\
\hline $\mathbf{1 3}$ & " & "D: & Stiepanoffsky. \\
\hline $\mathbf{1 4}$ & " & "D: & Pfeifer. \\
\hline $\mathbf{1 5}$ & " & "B: & Skržiwanek \\
\hline $\mathbf{1 6}$ & " & "D: & Fischer. \\
\hline $\mathbf{1 7}$ & " & B. & Schwertner. \\
\hline $\mathbf{1 8}$ & "drey kurze von Freudenthal & D & Woiet \\
\hline $\mathbf{1 9}$ & " & A: & ohne Verfasser \\
\hline $\mathbf{2 0}$ & " & Ex moli E. & Brixi \\
\hline $\mathbf{2 1}$ & " & "D: & Pokorny. \\
\hline $\mathbf{2 2}$ & " & Ex E: & Schneider. \\
\hline $\mathbf{2 3}$ & " & "D: & Pokorny. \\
\hline $\mathbf{2 4}$ & " & Ex A: moll. & Koenigsberger. \\
\hline $\mathbf{2 5}$ & ", & "Dis. & Wihner. \\
\hline $\mathbf{2 6}$ & " & "B: & Brixi. \\
\hline $\mathbf{2 7}$ & " & "g: & Doležalek. \\
\hline $\mathbf{2 8}$ & " & "G: & Hayden. \\
\hline $\mathbf{2 9}$ & " & F & ohne autor Organo Concerto. \\
\hline $\mathbf{3 0}$ & " & D: & Koenigsberger. \\
\hline
\end{tabular}

\begin{tabular}{|c|c|c|c|}
\hline Gegenstand. & Verfasser & Gegenstand & Verfasser. \\
\hline Missa Postorales (sic!) ex D: & Fritschek A.18.173 & Aria bey den H. Mess & \\
\hline 32 „Ex D: & dto. $A 18.163$ & 1 Ex D: & Zigenheim \\
\hline $33 \ldots, \mathrm{D}:$ & ohne autor & $2, C:$ & Žiadny. \\
\hline $34, F$ & dto & $3, F$ & ohne autor \\
\hline 35 Credo Sanctus ex D & Fritschek & $4 \mathrm{~B}$ & Mylli \\
\hline Offertorium & & $5 \mathrm{~B}$ & Fritschek A18.103 \\
\hline $1 \mathrm{ExD}$ & Fritschek $A 18.290$ & $6 \mathrm{D}$ & \begin{tabular}{|l|} 
ohne autor \\
\end{tabular} \\
\hline $2, A$ & dto A.18.086 & $7 \mathrm{D}$ & dto \\
\hline $3, \mathrm{~g}$ & \begin{tabular}{|l|} 
Schenkirž \\
\end{tabular} & $8 \mathrm{~B}$ & dto \\
\hline $4, D$ & Brixi & 9 moll C & Werner ohne \\
\hline $5, F$ & Fritschek A18.079 & $10 \mathrm{D}$ dur & ohne aut. \\
\hline $6, C$ & Vogel & $11 \mathrm{~B}$ & dto \\
\hline 21 , Dis & ohne author. & B & Fritschek \\
\hline $22, D$ & Schenkyrž & $12 \mathrm{~F}$ & ohne autor. \\
\hline $7, D$ & Brixi & $13 \mathrm{~B}$ & dto \\
\hline $8 \mathrm{~g}$ & Schenkyrž & $14 \mathrm{moll} \mathrm{g.}$ & dto \\
\hline $9 \mathrm{D}$ & ohne autor & $15 \mathrm{~A}$. & dto \\
\hline $10 \mathrm{D}$ & Pržibil & $16 \mathrm{~B}$ & dto \\
\hline $11 \mathrm{D}$ & Fritschek A18.091 & $17 \mathrm{Dis}$ & dto \\
\hline $12 \mathrm{D}$ & Matauschek & $18 \mathrm{~B}$ & dto \\
\hline $13 \mathrm{C}$ & Fritschek $A 18.095$ & $20 \mathrm{~B}$ & ohne \\
\hline $14 \mathrm{D}$ & \begin{tabular}{|l|} 
Brixi \\
\end{tabular} & $19 \mathrm{~F}$ & dto \\
\hline $15 \mathrm{D}$ & \begin{tabular}{|l|} 
Laube \\
\end{tabular} & molle & Werner \\
\hline $16 G$ & Schenkirž & $21 \mathrm{E}$ & Hasse \\
\hline
\end{tabular}


Jan Fryček in the Inventories of the Premonstratensian Monastery in Nová Řiše

\begin{tabular}{|l|l|l|l|}
\hline Gegenstand. & Verfasser & Gegenstand & Verfasser. \\
\hline $\mathbf{2 3} \mathrm{C}$ & Hoffmann & 22 Dis & Koželuh \\
\hline $\mathbf{1 7 G}$ & Lochelli & $\mathbf{2 3} \mathrm{B}$ & Peldrian \\
\hline$G$ & Schenkyž & $\mathbf{2 4} \mathrm{C}$ & Wanal \\
\hline $\mathbf{1 8 2 9} \mathrm{D}$ & dto & moll D & Fritschek \\
\hline $\mathbf{1 8} \mathrm{D}$ & Lochelli & $\mathbf{2 5} \mathrm{F}$ & ohne \\
\hline $\mathbf{2 0} \mathrm{C}$ & Condrad & $\mathbf{2 6} \mathrm{A}$ & Maschek. \\
\hline Offertorium pastoralis & & $\mathbf{2 7} \mathrm{A}$ & Wissner \\
\hline & & $\mathbf{2 8} \mathrm{B}$ & Riba \\
\hline $\mathbf{1 9}$ Ex D & Wisner & $\mathbf{2 9 G}$. & ohne \\
\hline & & $30 \mathrm{D}$ & ohne \\
\hline & & $31 \mathrm{Dis}$ & Hiebel \\
\hline
\end{tabular}

\begin{tabular}{|c|c|c|c|}
\hline Gegenstand. & Verfasser. & Gegenstand & Verfasser. \\
\hline \multicolumn{4}{|l|}{ beider Messe } \\
\hline 32 Aria ex C & Medek & 3 Salve Reguba ex D. & ohne autor \\
\hline "B & ohne & 4 Veni Sacte Spiritus C & Fritschek $A 18.286$ \\
\hline $33, C$ & Fritschek $A 18.033$ & $\begin{array}{l}5 \text { Ecce quomodo just } \\
\text { ex Dis }\end{array}$ & dto. A18.226 \\
\hline $34, C$ & Medek ohne & 6 dto $F$ & ohne \\
\hline $35, A$ & Fritschek & 7 Regina Coeli ex D & Chmel \\
\hline $36, F$ & dto. & $\begin{array}{l}8 \text { Te Deum } \\
\text { Laudamus C. }\end{array}$ & Pržibil \\
\hline $37, C$ & dto. A18.034 & 9 dto D & Fritschek \\
\hline $44, G$. & Martini & Littanyae ex C 1 & ohne \\
\hline $45 \mathrm{C}$ & dto & ${ }_{11} \mathrm{C} 2$ & Fritschek A18.289 \\
\hline $38 \mathrm{~B}$ & Wisner & ,D 3 & dto \\
\hline $39 \mathbf{G}^{29}$ & Fritschek $A 18.102$ & , D 4 & Pokorny \\
\hline $40-43 \mathrm{~F}$ & Fritsch dto $A 18.111$ & ${ }_{11} \mathrm{C} 5$ & dto \\
\hline Requiem: & & ${ }_{11} \mathrm{C} 6$ & dto \\
\hline 36 Ex moll A & Brixi & „1 $\mathrm{F} 7$ & Brixi \\
\hline $37, D$ & ohne & ${ }_{11} \mathrm{C} 8$ & Fritschek A18. 207 \\
\hline $38, F$ & Fritschek $A 18.118$ & , D 9 & Brixi \\
\hline 394045 & & ${ }_{11} \mathrm{C} 10$ & Pokorny \\
\hline \multicolumn{4}{|c|}{ Stationi festo Corp Xt: } \\
\hline $1 \mathrm{ExF}$ & Brixi Frits. A18.217 & Concerto ex F 1 & Fritschek. \\
\hline $2 \mathrm{D}$. & ohne Brixi & G 2 & ohne \\
\hline $3 \mathrm{~A}$ & Brixi & C 3 & Puchel \\
\hline $4 \mathrm{C}$ & Fritschek $A 18.216$ & $\mathrm{~F} 4$ & Hofmeister \\
\hline $5 \mathrm{D}$ & Loos & C5 5 & Puchmann \\
\hline $6 \mathrm{~F}$ & Fritschek $A 18.218$ & Symphonia ex B 1 & dto \\
\hline $7 \mathrm{G}^{30}$ & dto & Dis 2 & dto \\
\hline $8 \mathrm{~F}$ & Pichl & C 3 & Ditters \\
\hline Pangelingua. & & Dis 4 & Haydn \\
\hline
\end{tabular}

29 Formerly „F“.

30 Formerly „C“. 


\begin{tabular}{|l|l|l|l|}
\hline Gegenstand. & Verfasser. & Gegenstand & Verfasser. \\
\hline 1 ex Dis & ohne & A 5 & Ditters \\
\hline 2 B & Filla & BC 6 & Hayden \\
\hline 3 Dis & ohne & B 7 & Filla \\
\hline 4 C & Fritschek A17.999 & B 8 & ohne \\
\hline 5 C & Welitschek & moll D 9 & Fritschek A18.260 \\
\hline 6 C & Nawratil & F 10 & dto A18.262 \\
\hline 7 D. & ohne & C 11 & Hoffmann \\
\hline 8 D & Kratochwilla & F 12 & Veichtner \\
\hline Rorate & & & \\
\hline $\mathbf{1 7 2}$ ex G & Fritschek $A 18.273$ & C. 13 & Dittersdorf \\
\hline 2 14 G & dto & D. 14 & ohne \\
\hline 3 Z C & dto $A 18.272$ & & \\
\hline 4 13 C. & dto $A 18.269$ & & \\
\hline
\end{tabular}

\begin{tabular}{|c|c|c|c|}
\hline Gegenstand & Verfasser & Gegenstand & Verfasser. \\
\hline Quartetta ex B 1 & Stamitz & Ex Dis Trio 10 & Hayden \\
\hline B 2 & Hayden & B 19 & Fritschek chybí \\
\hline A 3 & dto & $\mathrm{F} \mathbf{2 0}$ & dto - II - \\
\hline 6 Quartetten 4 & $\operatorname{Kam}[\mathrm{m}] \|$ & B 13 & Stamitz chybí \\
\hline G. 5 & Hoffmeister & Dis 11 & Hayden \\
\hline A. 6 & Paradeiser & G. 14 & Fuchs Fuschs \\
\hline G.7 & Hoffmeister & Dis 17 & Hayden \\
\hline 7 Quartetti ex Dis & Anton Wranitzky chybí & $\mathrm{C}$ & Ditters \\
\hline $8 \mathrm{C}$ & Dasaur & Dis 18 & Hoffmann \\
\hline $9 \mathrm{G}$ & Gallo & E 15 & Saliyer \\
\hline $10 \mathrm{G}$ & Wanhal & $\mathrm{D}$ & Kammel \\
\hline Divertimento ex F moll & Demački & F 12 & Ivanschitz \\
\hline 2 B (přepsané na Dis) & Hayden & G 16 & dto \\
\hline $3 \mathrm{~F}$ & Wanehal & Duetto ex A 24 & \multirow{2}{*}{$\begin{array}{l}\text { Wutky } \\
\text { dto }\end{array}$} \\
\hline 4 Dis & Ivanschitz & $\mathrm{F}$ & \\
\hline $5 \mathrm{E}$ & Ditters & . & Prilinger \\
\hline 6 Dis & Lucca & G. 26 & Hayden \\
\hline $7 \mathrm{D}$ & dto & Parthia ex F 1 & Druschilzky \\
\hline $8 \mathrm{~F}$ & Hayden & D 2 & ohne \\
\hline $9 \mathrm{~F}$ & Rosetti & F 3 & Druschilzky \\
\hline $10 \mathrm{G}$ & Hoffmann & D 4 & Ditters \\
\hline $11 \mathrm{~B}$ & dto & D 5 & Fritschek \\
\hline 12 Dis & Hayden & G 6 & dto \\
\hline $\mathbf{F}$ & \begin{tabular}{|ll} 
Fritschek & Friček \\
A17.715 & \\
\end{tabular} & B 7 & dto $A 18.258$ \\
\hline 6. & Paul Wranitzky chybí & C 10 & Nudera \\
\hline 6. & dte & C9 & Thuret \\
\hline 6. & dto & F 12 & Druschilzky \\
\hline $14 \mathrm{~B}$ & Mikuletzky chybí & C 15 & Dspiler \\
\hline $15 \mathrm{D}$ & Hofmann & 2 Parthien 13 & Müller \\
\hline
\end{tabular}


Jan Fryček in the Inventories of the Premonstratensian Monastery in Nová Říše

\begin{tabular}{|l|l|l|l|}
\hline Gegenstand & Verfasser & Gegenstand & Verfasser. \\
\hline $\mathbf{1 7}$ D & Khamel & D 16 & Ditters \\
\hline $\mathbf{1 6}$ E & Mitscha Míča & F $\mathbf{8}$ & ohne \\
\hline $\mathbf{1 9}$ F & Aspelmayer & G. 17 & Vanerorovsky \\
\hline $\mathbf{1 8}$ Dis & Hayden & Dis 28 & Janda \\
\hline Trio ex C 1 & Apelmayer & Pleyelische Stücke & \\
\hline F 2 & Pleyel & Dis 23 & Koneczny \\
\hline F 3 & Hraal & Dis 14 & Müller \\
\hline F 4 & Pacherini & 3 parthien 29 & Wittwar \\
\hline D 5 & Rikert & Pamina et Sayra 27 & ohne autor \\
\hline C 5 & ohne & Ex Dis & Fritschek \\
\hline C 7 & ohne & C 11 & Nudera \\
\hline $\mathbf{8}$ & Cambini schazí & Dis 22 & Pichel \\
\hline $\mathbf{9}$ & Stamitz chybí & F 21 & Koželauch \\
\hline & & C 25 & ohne \\
\hline & & Dis 18 & Hofmeister \\
\hline & & Dis 19 & dto \\
\hline & & Dis 20 & dto \\
\hline
\end{tabular}

Troje česky Passiye a choralni listy

Neureisch den 30. July 1829

\author{
Johann Mach \\ Stifts=Organist
}

Mainhard Schuberth

d. z. Regenschori

The inventory lists 30 solemn masses. There are 4 masses from František Xaver Brixi, 2 from unspecified Pokorný, ${ }^{31} 2$ from Marian Königsberger and 2 from unspecified Novotný, ${ }^{32}$ while all the other composers are present only once. There is a significant share of Czech composers in the collection, e.g. Pokorný, Novotný, Jáchym Štěpanovský, ${ }^{33}$ or František Doležálek. ${ }^{34}$ There are also 4 pastoral masses and 1 missing Credo Sanctus

31 Violinist and a composer as well as a member of Oettingen-Wallerstein court orchestra František Xaver Pokorný (1729-1794) seems to be the most probable composer of the masses as four of his litanies were also part of the Fryček's collection (A18.206, A18.209, A18.210, A18.211).

32 It is possible that the composer of the masses is Josef Ondřej Novotný (1778-1856) (more about the composer in: ŠTĚDROŇ, Bohumír. Novotný Josef Ondřej. In ČERNUŠÁK, Gracián - ŠTĚDROŇ, Bohumír - NOVÁČEK, Zdenko (eds.). Československý hudebni slovnik osob a institucí. Sv. 2., Praha: Státní hudební vydavatelství, 1965, pp. 207-208.) as there are his Pastoral motetto in G (A30.518) and six of his menuets (A17.816). It could also be more or less unexplored Josef Novotný whose sacred compositions are to be found in various places in Prague (Strahov, Břevnov) or in Brno. More about him: ČERNUŠÁK, Gracián. Novotný Josef, 1. In ČERNUŠÁK, Gracián - ŠTĚDROŇ, Bohumír - NOVÁČEK, Zdenko (eds.). Československý hudebni slovnik osob a institucí. Sv. 2., Praha: Státní hudební vydavatelství, 1965, p. 207.)

33 Jáchym Štěpanovský (1775-1801) was a Czech regenschori and a composer of sacred music. His compositions are quite widespread and are to be found in Prague, Velvary, Český Krumlov, Nepomuk, or Roudnice. More about him in: ČERNUŠÁK, Gracián. Štěpanovský Jáchym. In ČERNUŠÁK, Gracián - ŠTĚDROŇ, Bohumír - NOVÁČEK, Zdenko (eds.). Československý hudebni slovnik osob a instituci. Sv. 2., Praha: Státní hudební vydavatelství, 1965, p. 738.

34 František Doležálek (?1772-?1844) was a Czech composer, probably a father of a composer and a teacher 
by Jan Fryček, 2 of the pastoral masses are from Jan Fryček as well. ${ }^{35}$ There are 24 offertories with 6 of them from Augustin Šenkýřr, ${ }^{36} 5$ from Fryček, and 3 by František Xaver Brixi. There are only 3 requiems - one by Brixi, one by unknown author and one from Fryček. There is also a pencil-written note with numbers 39, 40, 45 but the note does not list any possible authors, nor key signatures. There are 46 arias, but not all of them have a pencil written number next to them and some of them are struck through. ${ }^{37}$ There are 10 litanies -3 by Fryček, 4 by Fr. X. Pokorný and 2 by Brixi, the author of one of them is unknown. After the litany section comes the secular music divided into concertos (5) ${ }^{38}$, symphonies (14), divertimentos (19) ${ }^{39}$, quartets (12), trios (22), duets (4), and partitas (31). Works by the prominent composers of the end of the $19^{\text {th }}$ century, who spent a significant portion of their career at Vienna such as Franz Anton Hoffmeister, ${ }^{40}$ Jan Křtitel Vaňhal, Joseph Haydn, Franz Asplmayr have the largest representation. Some of the musical pieces in the inventory came also from Karl Ditters von Dittersdorf or Amandus Ivanschitz, whose compositions are in the Czech musical archives and in the collections of monasteries and churches quite frequent. Sadly, as far as the Smetana's catalogue goes, there is not a single surviving manuscript of Ivanschitz in the collection of Nová Říše. Although there are not as many, Fryček's compositions are to be found in almost every category - 1 concerto, 2 symphonies, 1 divertimento, 2 trios and 4 partitas.

Jan Emanuel Doležálek. Wiener Allgem. Musik Zeitung (1844, 52) writes about a certain Doležálek (without a first name) who was a "thorough musician and a former cantor at the Prague's choir loft". (Unspecified which choir loft exactly.) ŠTĚDROŇ, Bohumír. Doležálek František. In ČERNUŠÁK, Gracián - ŠTĚDROŇ, Bohumír - NOVÁČEK, Zdenko (eds.). Československý hudebni slovnik osob a institucí. Sv. 1., Praha: Státní hudební vydavatelství, 1963, p. 251.

35 CZ-Bm: A.18.163, A.18.173.

36 Augustin Šenkýř (1736-1796) was a Czech composer and Benedictine from the Emmaus Monastery. He is said to be a great organist, violinist and also a performer on the viola da gamba. His pieces are to be found mainly around Prague, in Moravia primarily at the places close to the border with Bohemia. More on him:

ČERNUŠÁK, Gracián. Šenkýř Augustin. In ČERNUŠÁK, Gracián - ŠTĚDROŇ, Bohumír - NOVÁČEK, Zdenko (eds.). Československý hudebni slovnik osob a institucí. Sv. 2., Praha: Státní hudební vydavatelství, 1965, pp. $686-687$.

37 Fryček's Aria in B, his Aria in D minor or Werner's Aria in C minor. Supposedly Medek's Aria ex C (number 34) has struck through his name and written "ohne" (without) in the column of authors. Benedikt Medek was a regenschori (1782) and cantor in Nová Ř́rše. It seems only his Aria in A (A18.087) survived in the musical collection. This aria does not however appear in the inventory no. 1.

38 The inventory does not specify for what instruments are specific concertos written. Fryček's concerto is currently missing, although at the time of the editing it was probably available as there is a pencil written number and there are no other notes.

39 Three bundles, each with 6 pieces, by Pavel Vranický are sadly missing. It is interesting that although brothers Vranický were born in Nová Řisśe, only three string quartets (bundled under one sign.) by Pavel Vranický survived in the musical collection of the monastery - A17.914.

A general insight into the lives of Vranický brothers can be found in: TESǍ̌, Stanislav. Kapitoly z hudební topografie: Nová Říše. Opus Musicum, 1970, č. 3, pp. 88-89.

40 Franz Anton Hoffmeister (1754-1812) was a German composer and a music publisher who at the age of 14 went to Vienna, where he studied the law. He published his own compositions but also the musical pieces of the most famous composers of the time, great deal of them were active in the Viennese musical life (Joseph Haydn, W. A. Mozart, L. van Beethoven, Johann Georg Albrechtsberger and others). He later on became one of the celebrated composers of the city and was a friend of W. A. Mozart or L. van Beethoven. 


\section{Fryček's surviving manuscripts}

The pencil-written notes were sufficient enough to identify Fryček's surviving compositions featured in the inventory no. 1. Some of them have dates of performances written on the last page of the sheet music. The following tables contain the signatures and basic information about all the compositions not only found in the inventory no. 1, but also surviving until this very day. Out of the surviving compositions, there is none that could not be found in this inventory. The names of the parts come from the labels of the parts themselves. If the specific part was missing, its name was taken from the title page of the manuscript.

\begin{tabular}{|l|l|}
\hline CZ-Bm: & Sign. A17.715 \\
\hline Nová Ř́iše Sign: & A 62 \\
\hline Title: & Divertimento ex F \\
\hline Movements: & Adagio, Menuett - Trio, Finale \\
\hline Parts: & Violino Primo, Violino Secondo, Oboa Solo, Violino Zello \\
\hline Performance: & - \\
\hline
\end{tabular}

\begin{tabular}{|l|l|}
\hline CZ-Bm: & Sign. A17.999 \\
\hline Nová Říše Sign: & B 15 \\
\hline Title: & Pange lingua in C \\
\hline Movements: & Adagio maestoso \\
\hline Parts: & $\begin{array}{l}\text { Canto, Alto, Tenore, Basso, Violino Solo, Violino Primo, Violino Secundo, Clarinetto } \\
\text { Primo, Clarinetto Secundo, Clarino Primo, Clarino Secundo, Tympani, Organo }\end{array}$ \\
\hline Performance: & - \\
\hline
\end{tabular}

\begin{tabular}{|l|l|}
\hline CZ-Bm: & Sign. A18.033 \\
\hline Nová Ř́ís Sign: & B 49 \\
\hline Title: & Aria, pro Omni festo \\
\hline Movements: & Molto, Andante \\
\hline Parts: & $\begin{array}{l}\text { Canto Solo, Violino Primo, Violino Secondo, Oboa Primo, Oboa Secundo, Viola di } \\
\text { Alto, Clarino Primo, Clarino Secundo, Organo }\end{array}$ \\
\hline Performance: & $\begin{array}{l}\text { 13th May 1799, 14th April 1800, 9th November 1800, 19th October 1801, 17th May } \\
1807\end{array}$ \\
\hline
\end{tabular}

\begin{tabular}{|l|l|}
\hline CZ-Bm: & Sign. A18.034 \\
\hline Nová Ř́iše Sign: & B 50 \\
\hline Title: & Aria in C \\
\hline Movements: & Allegro \\
\hline Parts: & $\begin{array}{l}\text { Soprano Solo, Violino Primo, Violino Secundo, Oboe Primo, Oboe Secundo, Viola, } \\
\text { Organo }\end{array}$ \\
\hline Performance: & 2nd May 1799, 13th May 1827 \\
\hline
\end{tabular}

\begin{tabular}{|l|l|}
\hline CZ-Bm: & Sign. A18.079 \\
\hline Nová Říše Sign: & B 96 \\
\hline
\end{tabular}




\begin{tabular}{|c|c|}
\hline Title: & Offertorium in F. Pro omni Tempore \\
\hline Movements: & Moderato \\
\hline Parts: & Canto, Alto, Tenore, Basso, Violino Primo, Violino Secondo, Organo \\
\hline Performance: & 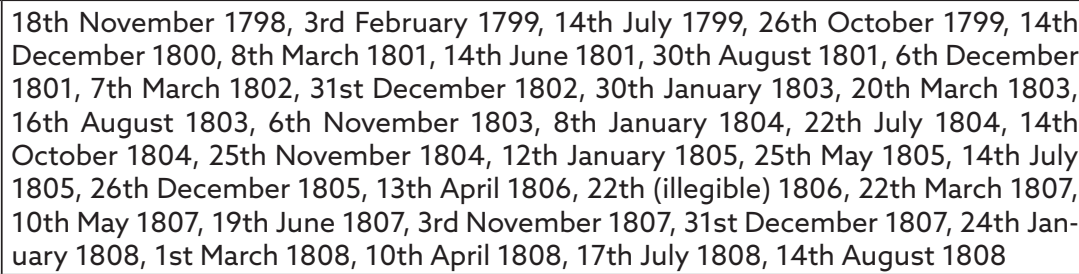 \\
\hline
\end{tabular}

\begin{tabular}{|l|l|}
\hline CZ-Bm: & Sign. A18.086 \\
\hline Nová Říše Sign: & B 103 \\
\hline Title: & Offertorium in A. Pro omni Tempore \\
\hline Movements: & Molto, Andante \\
\hline Parts: & $\begin{array}{l}\text { Canto, Alto, Tenore, Basso, Violino Primo, Violino Secondo, Cornu Primo, Cornu Sec- } \\
\text { ondo, Organo }\end{array}$ \\
\hline Performance: & $\begin{array}{l}\text { 20th May 1798, 23rd September 1798, 27th January 1799, 10th March 1799, 30th } \\
\text { November 1800, 1st February 1801, 12th April 1801, 21st June 1801, 20th December } \\
\text { 1801, 28th February 1802, 28th March 1802, 27th February 1803, 17th July 1803, } \\
\text { 9th October 1803, 12th February 1804, 24th December ?, 20th April 1806, 6th July } \\
\text { 1806, 30th August 1807, 3rd January 1808 }\end{array}$ \\
\hline
\end{tabular}

\begin{tabular}{|l|l|}
\hline CZ-Bm: & Sign. A18.091 \\
\hline Nová Ř́ře Sign: & B 108 \\
\hline Title: & Offertorium in D\#. De Nativitate Domini \\
\hline Movements: & Aria (All[egr]o moderato), Chorus (Presto) \\
\hline Parts: & Canto, Alto (solo), Tenore, Basso, Violino Primo, Violino Secundo, Alto Viola, Organo \\
\hline Performance: & - \\
\hline
\end{tabular}

\begin{tabular}{|l|l|}
\hline CZ-Bm: & Sign. A18.095 \\
\hline Nová Ř́íse Sign: & B 112 \\
\hline Title: & Offertorium in C. Pro festo S. S. Trinita \\
\hline Movements: & Molto \\
\hline Parts: & $\begin{array}{l}\text { Canto, Alto, Tenore, Basso, Violino Primo, Violino Secundo, Clarino Primo in C, Cla- } \\
\text { rino Secundo in C, Organo }\end{array}$ \\
\hline Performance: & $\begin{array}{l}\text { 7th December 1800, 31st May 1801, 9th August 1801, 26th October 1801, 29th No- } \\
\text { vember 1801, 13th June 1802, 15th August 1802, 24th December 1802, 5th June } \\
\text { 1803, 29th January 1804, 15th April 1804, 26th August 1804, 4th November 1804, } \\
\text { 2nd January 1805, 10th November 1805, 26th January 1806, 1st June 1806, 16th No- } \\
\text { vember 1806, 20th January 1807, 24th May 1807, 31st January 1808, 27th February } \\
\text { 1808, 12th June 1808, 11th July 1808 }\end{array}$ \\
\hline
\end{tabular}

\begin{tabular}{|l|l|}
\hline CZ-Bm: & Sign. A18.102 \\
\hline Nová Říše Sign: & B 119 \\
\hline Title: & Aria Ex G\#. De Nomine Jesu \\
\hline Movements: & Adagio dolce \\
\hline Parts: & Canto Solo, Violino Primo, Violino Secundo, Alto Viola obligat., Organo \\
\hline
\end{tabular}


\begin{tabular}{|l|l|}
\hline Performance: & 1st November 1800, 18th January 1801, 13th May 1801, 17th January 1802, 17th
\end{tabular} January 1803

\begin{tabular}{|l|l|}
\hline CZ-Bm: & Sign. A18.103 \\
\hline Nová Ř́iše Sign: & B 120 \\
\hline Title: & Aria ex B. Pro Festo Virginis \\
\hline Movements: & Allegro moderato \\
\hline Parts: & $\begin{array}{l}\text { Canto Solo, Violino Primo, Violino Secundo, Alto di Viola obligat., Violino 3tio vel } \\
\text { Alto Viola, Organo }\end{array}$ \\
\hline Performance: & 25th November 1798 \\
\hline
\end{tabular}

\begin{tabular}{|l|l|}
\hline CZ-Bm: & Sign. A18.111 \\
\hline Nová Ř́iše Sign: & B 128 \\
\hline Title: & Graduale \\
\hline Movements: & Largo \\
\hline Parts: & $\begin{array}{l}\text { Soprano Solo, Violino Primo, Violino Secundo, Oboa Primo, Oboa Secundo, Cornu } \\
\text { Primo (in F), Cornu Secundo (in C), Organo }\end{array}$ \\
\hline Performance: & - \\
\hline
\end{tabular}

\begin{tabular}{|l|l|}
\hline CZ-Bm: & Sign. A18.163 \\
\hline Nová Ř́iše Sign: & B 182 \\
\hline Title: & Missa Pastoralis in D\# \\
\hline Movements: & $\begin{array}{l}\text { Kyrie (Moderato), Gloria (Allegro), Credo (Molto), Sanctus (Adagio), Benedictus (An- } \\
\text { dante), Agnus Dei (Adagio), Dona nobis (Allegro) }\end{array}$ \\
\hline Parts: & $\begin{array}{l}\text { Canto, Alto, Tenore, Basso, Violino Primo, Violino Secundo, Clarino Primo in D, Cla- } \\
\text { rino Secundo in D, Tympano in D, Organo }\end{array}$ \\
\hline Performance: & - \\
\hline
\end{tabular}

\begin{tabular}{|l|l|}
\hline CZ-Bm: & Sign. A18.173 \\
\hline Nová Ř́še Sign: & B 192 \\
\hline Title: & Missa Pastoralis et Offertorium \\
\hline Movements: & $\begin{array}{l}\text { Kyrie (Tarde maestoso), Gloria (Allegro assai), Credo (Allegro, Adagio solo), Offerto- } \\
\text { rium Aria (Andante Solo), Chorus (Allegro), Sanctus (Allegretto), Agnus (Tarde Solo), } \\
\text { Dona nobis (Allegro) }\end{array}$ \\
\hline Parts: & $\begin{array}{l}\text { Canto, Alto, Tenore, Basso, Violino Primo, Violino Secundo, Clarino Primo in D, Cla- } \\
\text { rino Secundo in D, Tympano in D, Organo }\end{array}$ \\
\hline Performance: & $\begin{array}{l}\text { 1st January 1801, 1st January 1802, 1st January 1803, 11th January 1942, 30th De- } \\
\text { cember 1945, 6th January 1946 }\end{array}$ \\
\hline
\end{tabular}

\begin{tabular}{|l|l|}
\hline CZ-Bm: & Sign. A18.198 \\
\hline Nová Ř́ř́e Sign: & B 217 \\
\hline Title: & Reqviem ex F \\
\hline Movements: & $\begin{array}{l}\text { Kyrie (Largo), Dies irae (Largo), Lachrimosa (Largo Solo), Dona eis Requiem (Largo), } \\
\text { Offertorium (Tarde), Amplius (Andante Solo), Sanctus (Adagio), Osanna (Allabreve), } \\
\text { Benedictus, Agnus Dei (Andante Solo) }\end{array}$ \\
\hline Parts: & Canto, Alto, Basso, Violino Primo, Violino Secundo, Basso. Viol, Organo et Basso \\
\hline Performance: & - \\
\hline
\end{tabular}




\begin{tabular}{|l|l|}
\hline CZ-Bm: & Sign. A18.207 \\
\hline Nová Ř́še Sign: & B 226 \\
\hline Title: & Litaniae Lauretanae Ex C \\
\hline Movements: & $\begin{array}{l}\text { Kyrie (Moderato), Sancta Maria (Andante Solo), Virgo Prudentissima (Molto), Salus } \\
\text { infirmorum (Adagio Solo), Regina Angelorum (Allegro), Agnus Dei (Andante Solo) }\end{array}$ \\
\hline Parts: & $\begin{array}{l}\text { Canto (missing), Alto, Tenore, Basso (missing), Violino Primo, Violino Secundo, Or- } \\
\text { gano }\end{array}$ \\
\hline Performance: & - \\
\hline
\end{tabular}

\begin{tabular}{|l|l|}
\hline CZ-Bm: & Sign. A18.216 \\
\hline Nová Říše Sign: & B 235 \\
\hline Title: & Stationes Pro Festo S. S. Corporis Christi \\
\hline Movements: & $\begin{array}{l}\text { Statio I: O Salutaris (Moderato), Pinquis est (Andante Solo) } \\
\text { Statio II: Ecce panis Angelorum (Vivace), Cibavit eos (Adagio Solo) } \\
\text { Statio III: O, Sacrum convivium (Moderato), Caro mea (Adagio Solo) } \\
\text { Statio IV: Ave verum Corpus (Allegro moderato), Tantum ergo Sacramentum (Ada- } \\
\text { gio Solo) }\end{array}$ \\
\hline Parts: & Canto, Alto, Basso, Violino Primo, Violino Secundo, Violino41, Organo \\
\hline Performance: & - \\
\hline
\end{tabular}

\begin{tabular}{|l|l|}
\hline CZ-Bm: & Sign. A18.217 \\
\hline Nová Ř́iše Sign: & B 236 \\
\hline Title: & Modulus de Sacratissimo Corpore D. N. Jesu Christi \\
\hline Movements: & $\begin{array}{l}\text { Lauda Sion (Andante), Ecce panis angelorum (Andante), In figuris praesignatur (An- } \\
\text { dante), Jesu nostri miserere (Adagio) }\end{array}$ \\
\hline Parts: & $\begin{array}{l}\text { Canto, Alto, Tenore, Basso, Violino Primo, Violino Secundo, Clarinetto Primo in C, } \\
\text { Clarineto Secundo in C, Cornu Primo in F, Cornu Secundo in F, Organo }\end{array}$ \\
\hline Performance: & - \\
\hline
\end{tabular}

\begin{tabular}{|l|l|}
\hline CZ-Bm: & Sign. A18.218 \\
\hline Nová Ř́iše Sign: & B 237 \\
\hline Title: & Stationes Pro Festo S. S. Corporis Christi \\
\hline Movements: & $\begin{array}{l}\text { Statio 1ma: Sacris solemniis (Allegro moderato) } \\
\text { Statio 2da: Noctis recolitur (Moderato) } \\
\text { Statio 3tia: Post agnum typicum (Andante) } \\
\text { Stato 4: Dedit fragilibus (Moderato) }\end{array}$ \\
\hline Parts: & $\begin{array}{l}\text { Soprano Solo42, Violino Primo, Violino Secundo, Cornu Primo in F, Cornu Secundo in } \\
\text { F, Organo }\end{array}$ \\
\hline Performance: & - \\
\hline
\end{tabular}

\begin{tabular}{|l|l|}
\hline CZ-Bm: & Sign. A18.226 \\
\hline Nová Ř́iše Sign: & B 241 \\
\hline Title: & Ecce! quomodo justus moritur \\
\hline Movements: & Ecce quomodo moritur (Tarde) \\
\hline
\end{tabular}

41 The part is probably supposed to be played by a violist, although the part itself is notated with a treble cleff and the music never goes below $g$ (SPN: G3) and therefore could also be played by a violinist.

42 The Soprano solo is significantly more demanding than most of the solo parts in Fryček's different compositions. 


\begin{tabular}{|l|l|}
\hline Parts: & $\begin{array}{l}\text { Canto, Alto, Tenore, Basso, Clarinetto Primo in B, Clarinetto Secundo in B, Cornu } \\
\text { Primo in Dis, Cornu Secundo in Dis, Fagotto Primo (missing), Fagotto Secundo } \\
\text { (missing) }\end{array}$ \\
\hline Performance: & - \\
\hline
\end{tabular}

\begin{tabular}{|l|l|}
\hline CZ-Bm: & Sign. A18.258 \\
\hline Nová Ř́še Sign: & B 273 \\
\hline Title: & Parthia ex B \\
\hline Movements: & Allegro moderato, Menuetto, Trio, Andante, Rondo \\
\hline Parts: & $\begin{array}{l}\text { Violino Primo, Violino Secundo, Clarinetto Primo in B, Clarinetto Secundo in B, Vi- } \\
\text { olino Zello }\end{array}$ \\
\hline Performance: & - \\
\hline
\end{tabular}

\begin{tabular}{|l|l|}
\hline CZ-Bm: & Sign. A18.260 \\
\hline Nová Říše Sign: & B 276 \\
\hline Title: & Synphonia ex D \\
\hline Movements: & Andante poco, Allegro \\
\hline Parts: & $\begin{array}{l}\text { Violino Primo, Violino Secondo, Alto Viola, Oboa Primo, Oboa Secunda, Cornu vel } \\
\text { Clarino Primo ex D, Cornu vel Clarino Secundo ex D, Fundamento, Tympano }\end{array}$ \\
\hline Performance: & - \\
\hline
\end{tabular}

\begin{tabular}{|l|l|}
\hline CZ-Bm: & Sign. A18.262 \\
\hline Nová Říše Sign: & B 278 \\
\hline Title: & Synphonia \\
\hline Movements: & Allegro, Menuetto, Trio, Finale (Allegro) \\
\hline Parts: & $\begin{array}{l}\text { Viol. 1mo, Viol. 2do, Alto Viola, Viola di Alto, Oboa 1ma, Oboa 2do, Cornu 1mo in F, } \\
\text { Cornu 2 F, Basso }\end{array}$ \\
\hline Performance: & - \\
\hline
\end{tabular}

\begin{tabular}{|l|l|}
\hline CZ-Bm: & Sign. A18.269 \\
\hline Nová Říše Sign: & B 291 \\
\hline Title: & Rorate ex C \\
\hline Movements: & $\begin{array}{l}\text { Rorate Coeli (Allegro moderato), Caeli enarrant gloriam (Andante), Ecce Dominus } \\
\text { veniet (Andante), Alleluja (Alla breve) }\end{array}$ \\
\hline Parts: & Canto, Alto, Tenore, Basso, Violino Primo, Violino Secundo, Organo \\
\hline Performance: & - \\
\hline
\end{tabular}

\begin{tabular}{|l|l|}
\hline CZ-Bm: & Sign. A18.272 \\
\hline Nová Říše Sign: & B 294 \\
\hline Title: & Rorate \\
\hline Movements: & $\begin{array}{l}\text { Rorate Caeli (Allegro), Rorate Caeli (Allegro), Caeli enarrant gloriam (Andante, Canto } \\
\text { Solo) }\end{array}$ \\
\hline Parts: & Canto, Alto, Basso, Violino Primo, Violino Secundo, Organo \\
\hline
\end{tabular}

43 Parts Viola Alto and Viola di Alto are the same, but Viola Alto is notated in a treble cleff, while Viola di Alto is writen in an alto cleff. Both Cornu 1mo and Cornu $2 \mathrm{~F}$ are probably later additions as they are on separate papers and half the size of the rest of the manuscript. 


\section{\begin{tabular}{|l|l}
\hline Performance: & -
\end{tabular}}

\begin{tabular}{|l|l|}
\hline CZ-Bm: & Sign. A18.273 \\
\hline Nová Ř́̌̌e Sign: & B 295 \\
\hline Title: & Rorate ex G \\
\hline Movements: & $\begin{array}{l}\text { Rorate Caeli (Andante), Caeli enerant gloriam (Andante), Ecce Dominus veniet (An- } \\
\text { dante), Alleluja (Allabreve) }\end{array}$ \\
\hline Parts: & Canto, Alto, Tenore, Basso, Violino Primo, Violino Secundo, Organo ${ }^{44}$ \\
\hline Performance: & - \\
\hline
\end{tabular}

\begin{tabular}{|l|l|}
\hline CZ-Bm: & Sign. A18.286 \\
\hline Nová Ř́še Sign: & B 310 \\
\hline Title: & Veni Sancte Spiritus \\
\hline Movements: & Veni Sancte Spiritus (Allegro moderato), Accende Lumen sensibus (Andante Solo) \\
\hline Parts: & $\begin{array}{l}\text { Canto, Alto (missing), Tenore, Basso (missing), Violino Primo, Violino Secondo, Or- } \\
\text { gano }\end{array}$ \\
\hline Performance: & - \\
\hline
\end{tabular}

\begin{tabular}{|l|l|}
\hline CZ-Bm: & Sign. A18.289 \\
\hline Nová Ř́íse Sign: & B 313 \\
\hline Title: & Litanie Lauretane in C \\
\hline Movements: & $\begin{array}{l}\text { Kyrie (Moderato), Sancta (Andante Solo), Virgo prudentissima (Allegro), Salus infir- } \\
\text { morum (Adagio), Regina Angelorum, Agnus Dei (Andante Solo) }\end{array}$ \\
\hline Parts: & Canto, Alto, Tenore, Basso, Violino Primo, Violino Secondo, Organo45 \\
\hline Performance: & - \\
\hline
\end{tabular}

\begin{tabular}{|l|l|}
\hline CZ-Bm: & Sign. A18.290 \\
\hline Nová Ř́iše Sign: & B 314 \\
\hline Title: & Offertorium Ex D\#. Pro omni Tempore \\
\hline Movements: & Respice Domine (Allegro moderato) \\
\hline Parts: & $\begin{array}{l}\text { Canto, Alto, Tenore, Basso, Violino Primo, Violino Secundo, Alto Viola obligato, Cor- } \\
\text { nu Primo, Cornu Secundo, Organo46 }\end{array}$ \\
\hline Performance: & $\begin{array}{l}\text { 29th June 1798, 10th February 1799, 20th October 1799, 21st December 1800, 11th } \\
\text { October 1801, 14th February 1802, 13th March 1803, 22nd April 1804, 3rd February } \\
\text { 1805, 27th July 1806 }\end{array}$ \\
\hline
\end{tabular}

There are 28 of Fryček's surviving compositions, although 3 of them are missing parts. ${ }^{47}$ According to the inventory, there could have been up to 42 Fryček's musical pieces. Most of the surviving compositions written by Fryček belong to the sphere of sacred music. There are 5 surviving offertories, one though with only an organ part, 2

44 According to the note at the last page of the Organo part Fritschek finished the composition on the $3^{\text {rd }}$ of December 1791 .

45 All parts except Organo are missing. According to the note at the last page of Organo part Fryček finished the composition on the $26^{\text {th }}$ of November 1791 .

46 All parts except Organo are missing. Fryček finished the composition on the $16^{\text {th }}$ of February 1792.

47 Two Litaniae Lauretanae (A18.207, A18.289) and one offertory (A18.290). 
pastoral masses, one Pangelingue in C, 5 arias, 2 litanies, one requiem, 3 Rorate caeli and several shorter pieces (Ecce! quomodo justus, Veni Sancte, etc.). From the secular music is important to point out Fryček's Synphonia (A18.262) and Symphonia ex D (A18.260), his only surviving partita (A18.258) and especially his Divertimento ex $F$ (A17.715). ${ }^{48}$ Most performed of Fryček's surviving compositions were Offertorium in F. Pro omni Tempore (A18.079), Offertorium in A. Pro omni Tempore (A18.086), and Offertorium in C. Pro festo S. S. Trinita (A18.095) were in the beginning of the $19^{\text {th }}$ century performed quite extensively. ${ }^{49}$

Sadly, there is also a number of Fryček's compositions featured in the inventory no. 1 that cannot be traced and are currently lost. Some of them do not even have the pencilwritten number. ${ }^{50}$ Most of the compositions do have a pencil-written number, which suggests that at least at the time of the sorting these compositions were available. We can count Credo Sanctus ex D, Aria Ex A, Aria ex F, Stationi festo Corp Xt G, Te Deum D, Litany in $D$, Concerto ex $F$, Rorate in $G$ and two partitas in $\mathrm{D}$ and $\mathrm{G}$ among those compositions. Unfortunately, there are also two trios that have pencil written numbers but also a note "chybí" - missing. ${ }^{51}$ Some of the compositions miss only the specific part, but there is a possibility that these parts will be found in the upcoming research, for there is also a unordered bundle of parts not belonging to any specific compositions and without any signatures in Nová říše.

\section{Inventory No. 2}

The inventory no. 2, signed again both by Jan Mach and Mainhardt Schuberth, is also very similar to the older inventory made in 1826 by Josef Kallina, ${ }^{52}$ (to the point of being based on) but unlike Kallina's inventory it contains also list of duets, trios, quartets, quintets, sextets, symphonies and even some operas. Other than that, the musical pieces in both inventories are divided into the following groups Graduale (5), Offerium (5), Requiem (3), Salve Regina (2), Alma Redemptoris (2) and Rorate (13). Outside these categories are Lauda Sion ex A from Šrámek, 2 lamentations, Oratorium in C minor from John and two choral books, all these musical pieces are present in both Kallina's inventory from 1826 and in inventory no. 2 from Mach.

48 The divertimento was recorded (oboe Vladimír Pavlíček, violin Jiří Želák and Jan Ježek, violoncello Ludvík Píza) and broadcasted on the waves of Czech Radio Plzeň (programme Světem vážné hudby).

49 Offertorium in F. Pro omni Tempore has 35 dates of performance ranging from 1798 to 1808 , similarly $O f$ fertorium in A. Pro omni Tempore has 20 performances in 1798 to 1808. Offertorium in C. Pro festo S. S. Trinita has 24 performances from 1800 to 1808 .

50 Aria d moll, Pamina et Sayra ex Dis.

51 Trio in B flat, Trio in F.

52 CZ-Bsa: E 58, k. 252, f. 15. 


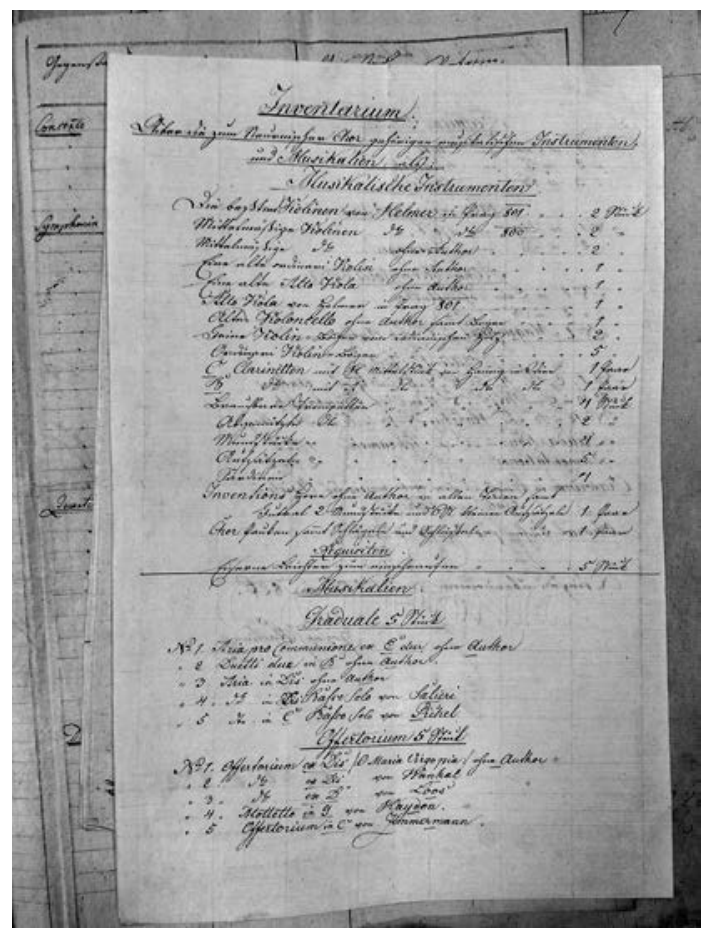

Fig. 5 Kallina's inventory

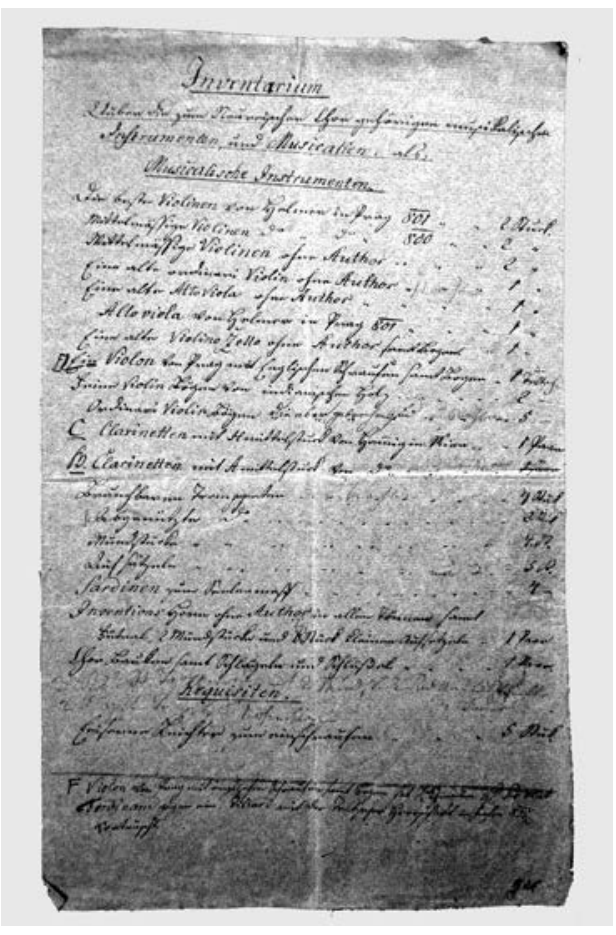

Fig. 6 Inventory no. 2

\title{
Transcription of the inventory no. 2
}

\author{
Inventarium
}

Über die zum Neureischen Chor gehörigen musikalischen Instrumenten, und Musicalien. als:

Musicalische Instrumenten:

Die beste Violinen von Helmer in Prag 801 " ", 2 Stück.

Mittelmässige Violinen $\mathrm{d}^{\circ}, \mathrm{d}^{\circ},{ }^{\prime} 800$, ", 2 ,"

Mittelmässige Violinen ohne Author " " " " 2 "

Eine alte ordinari Violin ohne Author " $" \| 1$,

Eine alte Alto Viola ohne Author " " " " "1 "

Alto viola von Helmer in Prag $801, \ldots, 1$,

Eine alte Violino Zello ohne Author samt Bogen ", " 1 ",

F Ein Violon von Prag mit Englischen Schraufen (sic!) samt Bogen „ 1 in Teltsch

Feine Violin Bögen von indianischen Holz ", ", ", 2 -

Ordinari Violin Bögen die aber gebrochen sind " , ", 5 -

C Clarinetten mit $\mathrm{H}$ mittelstuk von Ham[m]ig in Wien " " " 1 Paar

B Clarinetten mit A mittelstuck von $d^{\circ}$ " " " " 1 Paar

Brauchbaren Tromppeten , , " " 4 Stück

Abgenützte $d^{\circ}$ " ", , 2 Stück

Mundstücke " " " 4 St.

Aufsätzeln „" ", 5 St.

Sardinen zur Seelenmess " " " 4 - 
Inventions Horn ohne Author in allen Tönen samt

Futral 2 Mundstücke und 6 Stück kleinen Aufsetzeln „ „ „ „1 Paar

Chor Bauken samt Schlägeln und Schlüssel „ " , , 1 Paar

Requisiten.

Eisener Leicher zum einschraufen (sic!) ... 5 Stück

F Violon von Prag mit englischen Schraufen (sic!) samt Bogen hat S. Gnaden H. Prelat

Ferdinand gegen ein Biliard mit den Teltschen Herrschaft in Jahre 825

eingetauscht.

(new page)

Musicalien.

Gradualien 5 Stück

46 No. 1. Aria pro Communione ex E dur. ohne Author

"2. Duetti due in B ohne Author.

40,, 3 Aria in Dis ohne Author.

41. 4. $d^{\circ}$ in $C$ Basso Solo von Pichel

$425 \mathrm{~d}^{\circ}$ in Dis Basso Solo von Salieri

\section{Offertorium 5 Stück.}

No. 1. 24 Offertorium ex Dis O Maria Virgo pia ohne Author

"2 25 do ... ex Dis Von Wanhal.

" 326 do ... ex D von Loos.

„1 427 Motetto .. in G von Heyden.

", 528 Offertorium in C von Zimmermann.

Requiem 3 Stück.

No. 1. 39 Ex C moll von H. Laube.

„2. 40 Ex T (!) von Sedlacžek.

", 341 ex. Eb von Stross

Salve Regina 2 Stück

No. 1. ex Dis von Gölb

2, 2. in Dis von Zinsmeyer.

Alma Redemptoris 2 Stück

1 No. 1. ex E dur ohne Author

2 ,2. ex B do "

1 No. 1. Magnificat ex $C$ ohne Author.

Rorate 13 Stück

8 No.1_2_3_4_5_6_7_8. und 9. ohne Author ${ }^{53}$

No. 1014 ex D von Kžiž

„ 1115 ex Dmol von Raumbausek

(new page)

53 Over the numbers 1-9 are numbers 5-13 written in pencil. 
No. 72.16 ex B von Horžki

„, 1317 ex B bon Nowotny.

Lamenta Lauda Sion ex A von Schramek 1 Stück

Lamentationes 2 Stück

Oratorium in C mol Septem Verba morientis Christi

in Cruce von John

Choral Bücher pro Organo 2 Stück bis hieher all übernohmen am 31. Okt. 826

Duetten. No. 1. Ex dis ohne Author Dieser nebst den nach folgenden ist bey
„2. ex F ohne Author
S. gnaden H. Praelaten.

Trios No. 1 ex D ohne Author

„2. VI. Trios von Wendling in einem Band

"3. VI. do von M. Cambrini in einem Band

"4. VI. do von M. Kammel in einem Band

Quartetti. No 1. Ex D ohne Author
„2. Ex D. ohne Author
"3. in B von Hraab
"4. in F von Paradeiser
"5. in F von Klop.
"6. in B von Esser.
"7. ex D von Ordenz
"8. in C von Ordenz

Quintetti. No. 1. Die Bilgrimmen von Mekka von Gluck

No. 2. VI Quintetti von Boccherini

VI Sextetti von Boccherini in einem Band

Sinfonien. No. 1. Ex dis von Mitscha Míča ${ }^{54}$
"2. in $\mathrm{F}$ von Abel
"3. in A von Hayden
„4. ex G von Wanghal Waňhal
„5. ex D von Hayden.
„6. in A von Mitscha Míča
"7. in Dis von Wanhal

(new page)

Sinfonia No. 8. in D von Bach. Pugnani

No. 9. in $\mathrm{D}$ von Bach.

"10. VI Sinfonies von Filz in einem Band

"11. VI Sinfonies von verschiedenen Authoren

„, 12. Overtura ex D vo Misliveček. (sic!)

Concert a Flauto No. 1. Ex D von Hasse

d. N. 2. III Concertos a Flauto von Wanhal in einem Band

Oper

Arminda No 1. von Salieri

Teatro Capranica No. 2. von Fabrizi

Partituren

Opera No. 3 Die Bilgrimmen von Mekka. Authore Gluck.

in Partituren F. 4. Don Jean. (!) von Mozart in IV Theilen

F. 5 Zauberflete (!) von Mozart in III Theilen

F. 6. Figaro von Mozart in III Theilen

7. Palmira von Salieri in II Theilen

F. 8. Trofonio von Salieri in II Theilen

9. Pastorella von Guglielmi in II Theilen

54 Jan Adam František Míča (Jan Adam Franz Mitscha). More about him in: PERUTKOVÁ, Jana. Johann Adam Mitscha (1746-1811). Ein Wiener Zeitgenosse Mozarts. Studien zur Musikwissenschaft. Tutzing: Hans Schneider, 2007, Bd. 53, pp. 61-72. 
Neureisch den 26. August 825.

Milo Prix| ${ }^{55}$

Pfarkwes.

Johann Fritschek

Organist

F Die Opern Don Jean in 4. Theilen

„Z Zauberflete (!) in 3 Theilen

"Figaro in 3 Theilen

", Trophonio in 2 Theilen

Diese 4 Opern Don Jean, Zauberflete, Figaro und Trophonio in Parti

Turen wurden auf Befehl S. Gnaden H. Prelaten nach Teltsch dem pt.

H. Tobiaschek am 28ten November 1825 geliehen.

Neureisch den 30. Juli 1829

Mainhard Schuberth

Regenschori.

Johann Mach

Stiftsorganist.

The inventory no. 2 provides interesting information about the musical instruments in Nová Říse. Also, the inventory sometimes comments on the quality of the instruments and, for specific pieces, also lists the instrument maker. The monastery owned a pair of good quality violins (made in 1800) from the Prague violin maker Karel Josef Hellmer $(1739-1811)^{56}$ as well as a pair of medium-quality violins from the same maker from 1800. However, there are also featured some old ordinary violins. The viola from 1801 also came from Karel Hellmer's violin workshop. There are also featured clarinets by Friedrich Hammling from Wien. ${ }^{57}$

From the first half of the list of the musical pieces (the part featured both in Kallina's and in Mach's inventories) stands out Rorate $d$ moll from Adam Rambousek. ${ }^{58}$ In the part with the secular music stands out Quartet in $F$ from Benedictine composer Marian Paradeiser, who spent most of his life at Melk Abbey. There are also two quartets (A minor -

55 Milo Prixl (1790-1864) born in Moravské Budějovice (Mährisch Budwitz) was a priest, prior and an administrator of the monastery in Nová Říše (1821-1864). Mentioned in: RITSCHEL, Norbert. Personalstand der Secular und Regular Geistlichkeit der Brünner Diöcese in Mähren im Jahre 1841. Brünn: Franz Gastl, 1841, p. 134. Ondřej Madeja provides a list of the priests in Nová Říše among them is also Milo Prixl. More in: MADEJA, Ondřej. Kulturní život premonstrátského kláštera v Nové Řǐsi v letech 1848-1948 a jeho působeni na širokou veřejnost. České Budějovice, 2009. Master's thesis. University of South Bohemia in České Budějovice, Faculty of Education. Supervisor PhDr. et PaedDr. Jiří Dvořák, Ph.D.

56 Karel Josef Hellmer: A violin maker and a music publisher, born $1^{\text {st }}$ November 1739 , Prague, died $7^{\text {th }}$ October 1811, Prague. His work is similar to that of his father Johann Georg Hellmer.

ŠTĚDROŇ, Bohumír. Hellmer Karel Josef. In ČERNUŠÁK, Gracián - ŠTĚDROŇ, Bohumír - NOVÁČEK, Zdenko (eds.). Československý hudebni slovnik osob a institucí. Sv. 1., Praha: Státní hudební vydavatelství, 1963, p. 423.

57 More about him in: HAUPT, Helga. Wiener instrumentenbauer von 1791 bis 1815 . In Studien zur Musikwissenschaft. Österreich: Gesellschaft zur Herausgabe von Denkmälern der Tonkunst, Universität Wien, $1960,24$. Bd., p. 142.

58 There is a lively correspondence of Mainhard Schuberth with various members of Rambousek family stored in Moravský zemský archiv. Information about Rambousek family: ŠTĚDROŇ, Bohumír. Rambousek. In ČERNUŠÁK, Gracián - ŠTĚDROŇ, Bohumír - NOVÁČEK, Zdenko (eds.). Československý hudebni slovnik osob a institucí. Sv. 2., Praha: Státní hudební vydavatelství, 1965, p. 403. 
A17.817 and D major - A17.818) by Viennese composer Johann Karl von Ordonez, ${ }^{59}$ both are still part of the collection. Composers Jan Hraab or further unspecified Klop will be part of the future research. The inventory also features trios by Antonín Kammel ${ }^{60}$ and a flute player and composer of the Mannheim School Johann Baptist Wendling. Both survived in the musical collection of the monastery until this very day.

There are also several symphonies from Jan Adam František Míča (in E-flat and A), Jan Křtitel Vaňhal (in G and E-flat) and Haydn (in A and D). The inventory lists also six symphonies (A17.712) in a single bundle by composer Antonín Fils. ${ }^{61}$ There are also four concertos for flute - Concerto ex $D$ from Johann Adolf Hasse and three concertos from Vaňhal. There are no compositions by Fryček in this inventory.

The inventory features an important note about four operas lent to Telč in year 1825, namely Mozart's Don Juan (A17.968), Zauberflöte (A17.972), Figaro (A17.970) and Salieri's La grotta di Trofonio (A17.971). Other than these operas the inventory lists also Gluck's Die Pilgrime von Mekka, Salieri's Palmira, regina di Persia (A17.967) and Guglielmi's La pastorella nobile (A17.969). Nowadays the opera Die Pilgrime von Mekka as a whole is not present in the Smetana's catalogue which features only a quintetto (traverso flute, two violins, viola and violoncello) of the same name under sing. A17.720. The Gluck's opera is also the oldest one, as it was premiered in 1764. The rest of the operas come mainly from the $80 \mathrm{~s}$ and $90 \mathrm{~s}$ of $18^{\text {th }}$ century. ${ }^{62}$ Apart from the lent operas, we can presume a lively cooperation with nearby Telč chateau ${ }^{63}$ as not only operas were the subject of exchange - the Premonstratensians of Nová Ř́nśe also switched their violon for the billiard table during that very year. ${ }^{64}$

\section{Summary}

Both of the inventories stored in the archive of the Premonstratensian Monastery in Nová ̌ríše are incredibly valuable and able to shed light on the evolution of the musical

59 In the inventory written as "Ordenz". Johann Karl von Ordonez (1734-1786) was an Austrian part-time composer active mostly in Vienna.

60 Antonín Kammel (1730-1788) was a Czech composer active in Germany and later in London at the court orchestra. More in: ŠTĚDROŇ, Bohumír. Kammel Antonín. In ČERNUŠÁK, Gracián - ŠTĚDROŇ, Bohumír - NOVÁČEK, Zdenko (eds.). Československý hudebni slovnik osob a institucí. Sv. 1., Praha: Státní hudební vydavatelství, 1963, p. 638.

61 Antonín Fils (around 1730-1760) was a Czech composer active in Germany. He was a violoncello player in Mannheim and one of the most prominent members of the Mannheim court orchestra. More: ŠTĚDROŇ, Bohumír. Fils Antonín. In ČERNUŠÁK, Gracián - ŠTĚDROŇ, Bohumír - NOVÁČEK, Zdenko (eds.). Československý hudebni slovník osob a institucí. Sv. 1., Praha: Státní hudební vydavatelství, 1963, pp. 322-323.

62 La grotta di Trofonio (1785), Le nozze di Figaro (1786), Don Giovanni (1787), La pastorella nobile (1788), Zauberflöte (1791), Palmira, regina di Persia (1795).

63 A great deal of information about the theatrical life in Telč chateau are to be found in an article by Matthias Pernerstorfer: PERNERSTORFER, Matthias J. Ferdinand Raimund in Telč. Zu Schlosstheater und Theaterbibliothek der Grafen Podstatzky-Lichtenstein. Nestroyana, 2012, 32, Heft 1-2, pp. 33-46.

64 The end of the first page of the inventory no. 2. 
collection as well as on the former number of Fryček's composition. There is enough information to connect the names of the compositions written in the inventory no. 1 to specific musical pieces. It is an exceptional luck that most of the compositions not only by Fryček, but also by another local cantors are preserved and possible to study. However, the inventories serve not only as a list of Fryček's musical pieces, but they also help to understand the greater structure on the secular part of the collection. The categories and the number of compositions speak clearly in favour of chamber music, the most popular being partitas and trios. Quite favourite were also quartets and mainly symphonies. It is also principal to notice the preferred authors of the musical pieces which in many cases were the important figures of musical life in Vienna of the end of the $18^{\text {th }}$ century. Undeniably noteworthy is also a portion of the compositions by the authors from the Czech lands. Several of those are still almost unknown and will be addressed in the upcoming examination. Additionally, the covers of the sheet music contain a significant number of dates of performances and thus allow to at least partially evaluate the musical life in Nová Řišse. ${ }^{65}$ We might say that the music by the local cantors and composers was more than popular in Nová Říse. Another interesting part of the collection are the operas and their purpose in the monastery. Cursory research suggests that some arias of these operas were arranged for chamber ensembles (e.g. Gluck's Die Pilgrimme von Mecca or quartet labelled as by anonymous stored under sign. A17.945 which proven to be an arranged aria Non so più cosa son, cosa faccio from Mozart's Le nozze di Figaro). There are probably many more arranges labelled as anonymous that are in fact parts of famous operas. The authorship recognition is going to be a crucial part of the further research. The inventories also give an indisputable proof of the lively contact with the brotherhood in Telč. This study focuses solely on the work of Jan Fryček, but there is a great amount of information any interested person can harvest from these two relatively short, yet informative inventories.

\section{Bibliography}

\section{Sources}

CZ-Bm: Sign. A17.715. Jan Fryček - Divertimento ex F

CZ-Bm: Sign. A17.812. Wolfgang Amadeus Mozart - Ouverture from Don Juan

CZ-Bm: Sign. A17.859. Antonio Salieri - Armida

CZ-Bm: Sign. A17.968. Wolfgang Amadeus Mozart - Don Giovanni

CZ-Bm: Sign. A17.969. Pietro Alessandro Guglielmi - La pastorella nobile

CZ-Bm: Sign. A17.970. Wolfgang Amadeus Mozart - Le nozze di Figaro

CZ-Bm: Sign. A17.971. Antonio Salieri - La Grotta di Trofonio

CZ-Bm: Sign. A17.972. Wolfgang Amadeus Mozart - Die Zauberflöte

65 Interesting and insightful information about the musical life in Nová Říše and about the performances within the liturgical year are to be found in seminar paper: OLŠANSKÁ, Ludmila. Hudebni sbírka kláštera premonstrátů v Nové Řiši . Brno: Ústav hudební vědy, 1997. Seminar paper. Supervisor PhDr. Stanislav Tesař. 
CZ-Bm: Sign. A17.999. Jan Fryček - Pange lingua in $C$

CZ-Bm: Sign. A18.033. Jan Fryček - Aria, pro Omni festo

CZ-Bm: Sign. A18.031. Jan Fryček - Aria in C

CZ-Bm: Sign. A18.079. Jan Fryček - Offertorium in F. Pro omni Tempore

CZ-Bm: Sign. A18.086. Jan Fryček - Offertorium in A. Pro omni Tempore

CZ-Bm: Sign. A18.091. Jan Fryček - Offertorium in D\#. De Nativitate Domini

CZ-Bm: Sign. A18.095. Jan Fryček - Offertorium in C. Pro festo S. S. Trinita

CZ-Bm: Sign. A18.102. Jan Fryček - Aria Ex G\#. De Nomine Jesu

CZ-Bm: Sign. A18.103. Jan Fryček - Aria ex B. Pro Festo Virginis

CZ-Bm: Sign. A18.111. Jan Fryček - Graduale

CZ-Bm: Sign. A18.163. Jan Fryček - Missa Pastoralis in D\#

CZ-Bm: Sign. A18.173. Jan Fryček - Missa Pastoralis et Offertorium

CZ-Bm: Sign. A18.198. Jan Fryček - Requiem ex F

CZ-Bm: Sign. A18.207. Jan Fryček - Litaniae Lauretanae Ex C

CZ-Bm: Sign. A18.216. Jan Fryček - Stationes Pro Festo S. S. Corporis Christi

CZ-Bm: Sign. A18.217. Jan Fryček - Modulus de Sacratissimo Corpore D. N. Jesu Christi

CZ-Bm: Sign. A18.218. Jan Fryček - Stationes Pro Festo S. S. Corporis Christi

CZ-Bm: Sign. A18.226. Jan Fryček - Ecce! quomodo justus moritur

CZ-Bm: Sign. A18.258. Jan Fryček - Parthia ex B

CZ-Bm: Sign. A18.260. Jan Fryček - Synphonia ex D

CZ-Bm: Sign. A18.262. Jan Fryček - Synphonia

CZ-Bm: Sign. A18.269. Jan Fryček - Rorate ex $C$

CZ-Bm: Sign. A18.272. Jan Fryček - Rorate

CZ-Bm: Sign. A18.273. Jan Fryček - Rorate ex $G$

CZ-Bm: Sign. A18.286. Jan Fryček - Veni Sancte Spiritus

CZ-Bm: Sign. A18.289. Jan Fryček - Litanie Lauretane in $C$

CZ-Bm: Sign. A18.290. Jan Fryček - Offertorium Ex D\#. Pro omni Tempore

CZ-Bm: 85.233/G 2.158, 85.234/G 2.159, 85.235/G 2.160, G 26. Inventories

CZ-Bsa: E 58, k. 252, f. 11-19. Inventories

\section{Literature}

ČERNUŠÁK, Gracián - ŠTĚDROŇ, Bohumír - NOVÁČEK, Zdenko (eds.). Československý hudebni slovnik osob a institucí. Sv. 1., Praha: Státní hudební vydavatelství, 1963.

ČERNUŠÁK, Gracián - ŠTĚDROŇ, Bohumír - NOVÁČEK, Zdenko (eds.). Československý hudebni slovnik osob a institucí. Sv. 2., Praha: Státní hudební vydavatelství, 1965.

FUKAČ, Jiří. Zur inneren Systematik musikalischer Verzeichnisgattungen. In VYSLOUŽIL, Jiř́i (ed.). Sbornik praci Filozofické fakulty brněnské univerzity. Brno: Universita J. E. Purkyně, 1967, roč. 16 , č. H2, pp. 21-30.

HAUPT, Helga. Wiener instrumentenbauer von 1791 bis 1815. In Studien zur Musikwissenschaft. Österreich: Gesellschaft zur Herausgabe von Denkmälern der Tonkunst, Universität Wien, 1960, 24. Bd., p. 142.

MADEJA, Ondřej. Kulturni život premonstrátského kláštera v Nové Řiši v letech 1848-1948 a jeho puisobeni na širokou veřejnost. České Budějovice, 2009. Master’s thesis. University of South Bohemia in České Budějovice, Faculty of Education. Supervisor PhDr. et PaedDr. Jiří Dvořák, Ph.D. 
MAŇAS, Vladimír. Hudební tradice. In NEKUDA, Vladimír. Dačicko, Slavonicko, Telčsko. Brno: Muzejní a vlastivědná společnost v Brně, 2005. pp. 402-407.

MAŇAS, Vladimír. K problematice hudebních inventářů: několik doplňujících poznámek k heslu Katalog Jiřího Fukače ve Slovníku české hudební kultury. Musicologica Brunensia. 2016, roč. 51, č. 2, pp. 81-94.

OLŠANSKÁ, Ludmila. Hudebni sbirka klâštera premonstrátư v Nové Řišii. Brno: Ústav hudební vědy, 1997. Seminar paper. Supervisor PhDr. Stanislav Tesař.

PAŘEZ, Jan - KROUPA, Jiří. NOVÁ ŘÍŠE (Jihlava) Bývalý konvent premonstrátek Matky Boží (P. Marie) s kostelem sv. Petra a Pavla, následně kanonie premonstrátů. In FOLTÝN, Dušan a kol. Encyklopedie morauských a slezských klášterů. Praha: Libri, 2005, pp. 456-460.

PERNERSTORFER, Matthias J. Ferdinand Raimund in Telč. Zu Schlosstheater und Theaterbibliothek der Grafen Podstatzky-Lichtenstein. Nestroyana, 2012, 32, Heft 1-2, pp. 33-46.

PERUTKOVÁ, Jana. Johann Adam Mitscha (1746-1811). Ein Wiener Zeitgenosse Mozarts. Studien zur Musikwissenschaft. Tutzing: Hans Schneider, 2007, Bd. 53, pp. 61-72.

RITSCHEL, Norbert. Personalstand der Secular und Regular Geistlichkeit der Brünner Diöcese in Mähren im Jahre 1841. Brünn: Franz Gastl, 1841, p. 134.

SVOBODOVÁ-PALEČKOVÁ, Věra. Hudební sbírka kláštera premonstrátů v Nové Říši. Časopis Moravského muzea v Brně. XXXVI-1951, p. 3.

TESǍ̌, Stanislav. Kapitoly z hudební topografie: Nová Říše. Opus Musicum, 1970, č. 3, pp. 88-89. VETTERL, Karel. Volkslied-Sammelergebnisse in Mähren und Schlesien aus dem Jahre 1819. In VYSLOUŽIL, Jiří (ed.). Sbornik prací Filozofické fakulty brněnské univerzity. Brno: Universita J. E. Purkyně, 1973, roč. 22, č. H8, p. 103, 106, 107, 115.

VETTERL, Karel - HRABALOVÁ, Olga. Guberniálni sbírka pisni a instrumentálni hudby z Moravy a Slezska z roku 1819. Strážnice: Ústav lidové kultury, 1994

ŽÍDECKÝ, Cyril. Beschreibung und kurze Geschichte des Prämonstratenser-Chorherrenstiftes Neu-Reisch in Mähren. Würzburg \& Wien: Verlag von Leo Woerl, 1882. 
